Atmos. Chem. Phys. Discuss., 6, 11299-11316, 2006 www.atmos-chem-phys-discuss.net/6/11299/2006/

(c) Author(s) 2006. This work is licensed under a Creative Commons License.
Atmospheric

Chemistry and Physics Discussions

\title{
Interannual variability and long term changes in planetary wave activity in the middle atmosphere observed by lidar
}

A. Hauchecorne, P. Keckhut, and M. L. Chanin

Service d'Aéronomie/IPSL, CNRS, UVSQ, UPMC, France

Received: 22 September 2006 - Accepted: 2 November 2006 - Published: 14 November 2006

Correspondence to: A. Hauchecorne (alain.hauchecorne@aerov.jussieu.f)
Variability of planetary wave activity observed by lidar

A. Hauchecorne et al.

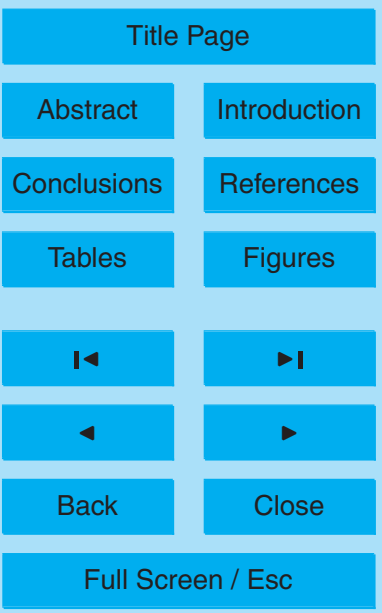

Printer-friendly Version 


\section{Abstract}

The upwelling planetary wave activity (PW) from the troposphere controls the intensity of the equator to pole transport of stratospheric ozone by the Brewer-Dobson circulation and thereby modulates the total ozone content at mid- and high-latitudes. Rayleigh

5 lidar temperature data obtained from 1981 to 2001 at mid-latitude were used to study the interannual variability of PW activity in winter (October to April). The spectrum of stratospheric temperature fluctuations exhibits 2 peaks corresponding to 2 dominant modes of free travelling Rossby waves known as 16 day- and 12 day-waves. The 12 day-wave activity is shown to be anticorrelated with the equatorial QBO wind at $40 \mathrm{hPa}$.

During the period 1981-2000 the global PW activity shows a negative trend for months October to January and a positive trend in March and April.

\section{Introduction}

The middle atmosphere thermal structure is expected to change due to the increase of greenhouse gases and the depletion of stratospheric ozone. The radiative effect of greenhouse gases is positive in the lower and middle troposphere, but becomes negative as soon as the infrared optical thickness of the atmosphere is low enough to allow the thermal radiation to be emitted directly to space, i.e. in the upper troposphere, stratosphere and mesosphere. The temperature is also affected by changes in ozone which is an important greenhouse gases in the stratosphere. The decrease of stratospheric ozone until mid 1990s and its stabilisation afterwards have contributed significantly to the cooling of lower stratosphere (Ramaswamy et al., 2001).

The temperature in the winter polar stratosphere is controlled by the activity of planetary waves (PW) leading to sudden stratospheric warming (Labitzke, 1981). The meridional (equatorward or poleward) and upward propagation of $\mathrm{PW}$, is driven by the thermal and wind structure of the middle atmosphere (Matsuno, 1971) and can be represented using a refractive index of PW (O'Neill and Youngblut, 1982). The PW

\section{Variability of planetary wave activity observed by lidar}

A. Hauchecorne et al.

Title Page

Abstract

Introduction

Conclusions

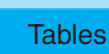

References

Tables

Figures

14

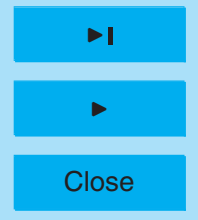

Back

Full Screen / Esc

Printer-friendly Version

Interactive Discussion 
forcing on the mean flow is characterized by the convergence of the EP flux. Expected radiative changes are latitude dependent and cause changes in the meridional gradient of pressure inducing a change in the propagation of planetary Rossby waves in the winter middle atmosphere. Cordero and Nathan (2005) have shown that changes in 5 stratospheric ozone are sufficient to induce radiative changes in the temperature field that can modify the refractive index of PW and can affect the large-scale circulation. The sign of the radiative-dynamical feedback is still unknown. General climate models predict either intensification or weakening of stratospheric warmings during the next decades (Austin et al., 2003).

10 Following the reduction of CFCs emissions, the stratospheric ozone layer is expected to recover during the next decades. However mechanisms at the origin of ozone depletion are highly non-linear and any change in the thermal structure of the polar stratosphere may affect the rate of recovery. Chorine species involved in the catalytic cycle of ozone destruction are activated by heterogeneous reactions at the surface of PSC 15 particles. If the temperature goes down faster than expected due to a decrease of $P W$ activity, the frequency of occurrence of PSCs will strongly increase and the recovery will be delayed by several decades. On the contrary, if the temperature goes up due to an increase of PW activity, the recovery will be faster than expected.

The detection of changes requires long series of measurements and a good estimate of the natural variability (Keckhut et al., 1995). PW upward propagation represents one of the main causes of variability of the middle atmospheric temperature. Extratropical Rossby planetary waves are generated in the troposphere and can propagate upwards in the middle atmosphere during the period of westerly winds in the stratosphere from October to April. During the summer period their vertical propagation is blocked by easterly winds (Charney and Drazin, 1961). Unfortunately, they are very few dataset available to study changes in the dynamics of the upper stratosphere and the mesosphere, and when they exist most of them are limited in the length of the series, in the range covered or in the height resolution. One of the best available dataset is the one provided by the Rayleigh lidar at Haute-Provence Observatory (OHP; 44N, 6E),

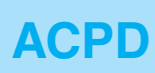

6, 11299-11316, 2006

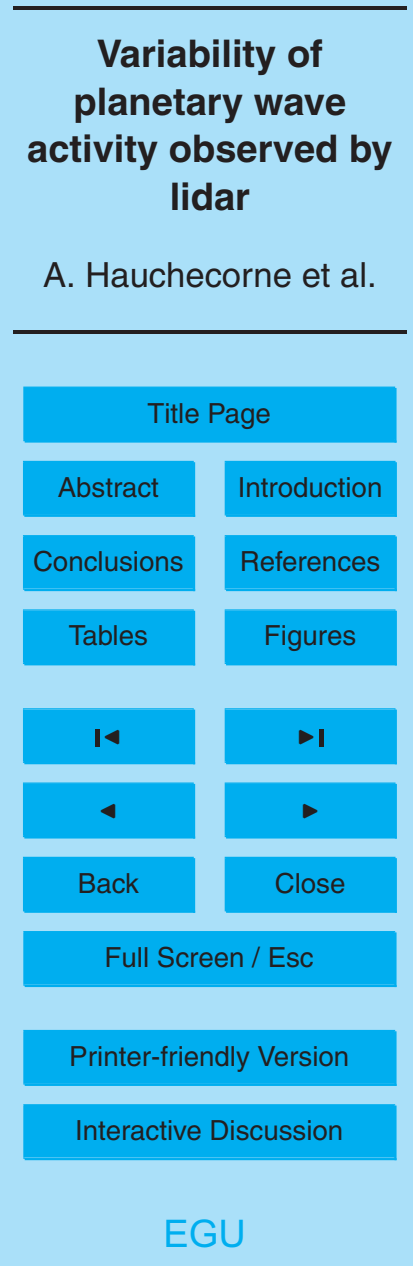


operated regularly since 1979 to measure vertical profiles of temperature from 30 to $80 \mathrm{~km}$. This instrument is integrated in the Alpine station of the Network for the Detection of Atmospheric Composition Change (NDACC, formerly NDSC). Lidar and rocket data have been used for several studies of planetary wave propagation in the middle 5 atmosphere (Hauchecorne and Chanin, 1983; Hauchecorne et al., 1987; Offermann et al., 1987; Bittner et al., 1994), but they were limited in time. In the present study we analyse OHP lidar data to estimate the planetary wave activity during each winter from 1981-1982 to 2000-2001. The evolution of the PW activity during these 20 years will be presented. The role of the Quasi-Biennial Oscillation (QBO) in the modulation of 10 PW activity will be also discussed.

\section{Database and data processing}

Data are obtained using the Rayleigh lidar set-up at OHP. The lidar provides vertical profiles of temperature above about $30 \mathrm{~km}$, in the region free of aerosols (Hauchecorne et al., 1980). Basically the method consists in measuring the atmospheric density in 15 relative value, assumed to be proportional to the intensity of the backscattered Rayleigh signal. The temperature profile is obtained in absolute value by a downward integration of the hydrostatic law assuming a pressure at the top of the profile $(\sim 90 \mathrm{~km})$ equal to the pressure of MSIS90 climatology (Hedin, 1991).

Lidar data are integrated during one night of measurement and are smoothed to 20 suppress short scale fluctuations induced for instance by gravity waves (Hauchecorne et al., 1991). The resulting vertical resolution is $3 \mathrm{~km}$ and the vertical sampling is $1 \mathrm{~km}$. The typical accuracy is better than $2 \mathrm{~K}$ up to $70 \mathrm{~km}, 5 \mathrm{~K}$ at $80 \mathrm{~km}$ and $20 \mathrm{~K}$ at $90 \mathrm{~km}$ (Keckhut et al., 1993).

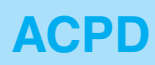

6, 11299-11316, 2006

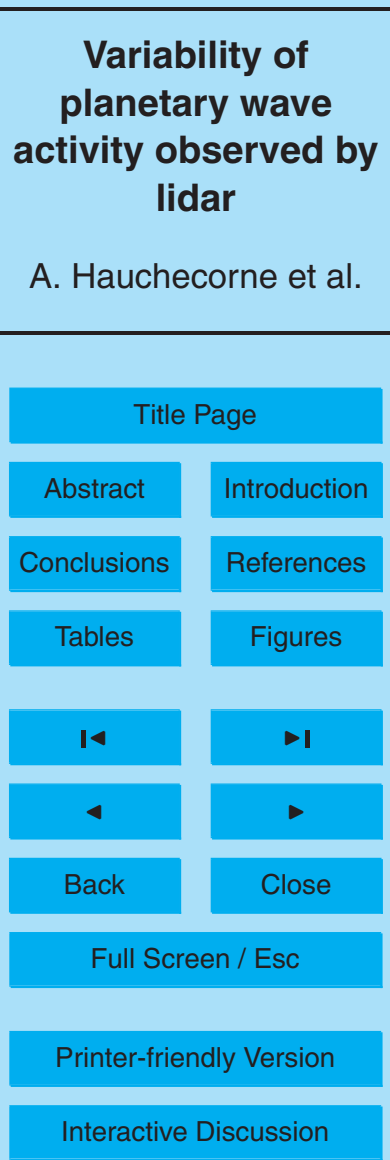


For each year the period from 90 days before to 120 days after 1 January (from October to April) is selected. Temperature data are interpolated in time using modified cubic spline functions (Hauchecorne et al., 1991) at each altitude to fill gaps due to missing 5 data. Figure 1 presents the temperature evolution during winter 1996-1997. Temperature perturbations with periods ranging from a few days to 20 days are clearly visible in the upper stratosphere and in the mesosphere. They are due to the propagation of PW. As expected, the amplitude is maximal in mid-winter when strong westerly winds favour the upward propagation of PW. For the interpretation of these observations we have to keep in mind that a fixed ground-based lidar samples temperature perturbations occurring above the site but does not separate reversible processes like free travelling planetary waves from irreversible ones like sudden stratospheric warmings.

\subsection{Spectral analysis}

Free planetary Rossby waves have preferential periods depending on their zonal wave 15 number and their mode (Kasahara, 1980). In the north winter stratosphere, the socalled 16-day wave-zonal number 1 and 12-day-wave-number 2 are dominant because higher wave numbers are absorbed in the lower stratosphere. In order to detect if such waves are present, we perform at each altitude a spectral analysis of the temperature deviation from winter average. A Welch window is applied before the analysis to avoid side effects. Winters are classified according to the phase of the QBO defined as the sign of the averaged equatorial zonal wind in January-February at $40 \mathrm{hPa}$ (Table 1). For both phases of the QBO, 2 maxima are observed in altitude, the first one in the upper stratosphere around $40 \mathrm{~km}$, clearly associated to $\mathrm{PW}$ and limited to frequencies lower than 0.1 day $^{-1}$ (periods longer than 10 days), and the second one in the mesosphere above $60 \mathrm{~km}$, extending to higher frequencies and attributed by Hauchecorne et al. (1991) to a combination of PW and the effect of gravity wave breaking on the mean temperature. For QBO West (Fig. 2, top), a broad frequency peak is observed at

\section{Variability of planetary wave activity observed by lidar}

A. Hauchecorne et al.

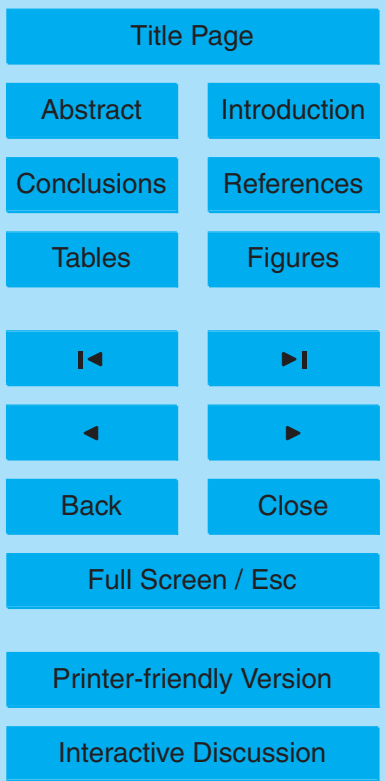


$40 \mathrm{~km}$ at $0.050-0.055$ day $^{-1}$ (18-20 days). For QBO East (Fig. 2, bottom) two sharper peaks are detected at the same altitude at 0.055 day $^{-1}$ (18 days) and at 0.075 day $^{-1}$ (13 days). These two peaks correspond broadly to the two dominant 12 day- and 16 day-Rossby waves in the north winter stratosphere. The shift towards longer periods 5 may be explained by the Doppler shift due to the wave propagation in westerly winds. Mesospheric results are more difficult to interpret due to a combination of effects, but the presence of the 18-20 days period is observed for all situations.

In order to see if the QBO is truly at the origin of the modulation of the 12 day-wave amplitude, the PW energy has been averaged for each winter in a period interval 10.9 to 14.6 days. This period interval is representative of the 12 day-wave. In the upper stratosphere, the energy of the 12-day wave exhibits clearly a quasi-biennial periodicity with some variation in the altitude of energy maxima between 38 and $45 \mathrm{~km}$ (Fig. 3). The evolution of its energy averaged over the altitude range $38-45 \mathrm{~km}$ (Fig. 4) is well correlated with the amplitude of the equatorial wind at $40 \mathrm{hPa}$. Each maximum in the energy curve corresponds to a minimum in the wind amplitude and the correlation coefficient is equal to $-0.45 \pm 0.21$, significant at the $95 \%$ level ( 2 standard deviations).

The scatter plot presented in Fig. 5 visualizes this anticorrelation. There is some significant scatter around the regression line but the 3 years with highest energy (1984, 1987 and 1992) are in the QBO east category. The year 1987 is far over the regression line. It corresponds to winter 1986-1987 with a major stratospheric warming in January 1987 (Naujokat, 1987).

\subsection{Trend in planetary wave activity}

Changes in the atmospheric temperature and wind structure may induce modifications in the propagation of $\mathrm{PW}$ in the stratosphere. These modifications may have some seasonal evolution. It is therefore interesting to investigate if such a trend varies during the winter. In fact during the period 1982-2000 a negative trend is detected from October to January, a zero trend in February and a positive trend in March-April (Fig. 6).

\section{Variability of planetary wave activity observed by lidar}

A. Hauchecorne et al.

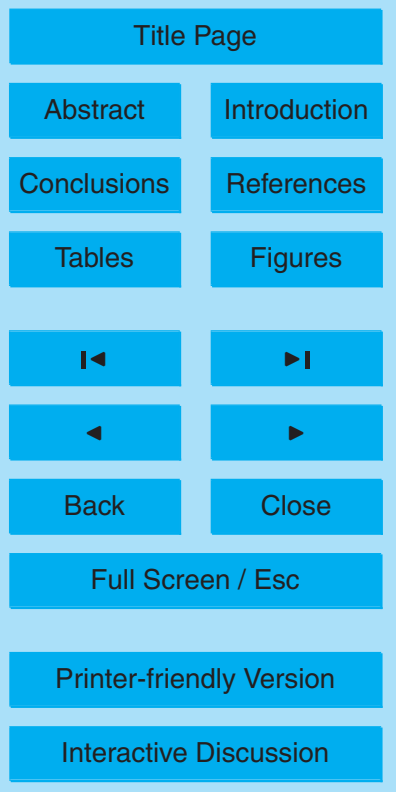


This indicates that the maximum of PW activity is occurring later in the winter at the end of the period under study.

\section{Discussion}

The present work confirms the existence of preferential periods in the spectrum of PW 5 in winter around 12-13 and 18 days. Similar periodicities have been reported in previous studies. Hauchecorne et al. (1983) using a much shorter series of OHP data demonstrated the continuous activity of planetary waves as long as prevailing winds at mid-latitude are westerly (from October to April) and detected the frequent occurrence of a 18 day-travelling Rossby wave. In a later publication, Hauchecorne et al. (1987) showed the presence of 12.5 day westward propagating Rossby wave during MAPWINE campaign in winter 1983-1984 using lidar and rocket observations above Europe. The 12 day-wave was also detected by Offermann et al. (1987) with a harmonic analysis of temperature oscillations during the same campaign. The 2 periods around 18 days and $12-12.5$ days correspond approximately to the 2 dominant 16 day-number 151 and 12 day-number 2 Rossby waves in the northern winter hemisphere (Kasahara et al., 1980).

The influence of the equatorial QBO on extra-tropics was first demonstrated by Holton and Tan (1980) who showed, using National Meteorological Center daily analyses, that the geopotential at $50 \mathrm{hPa}$ in northern high latitudes was lower during the west phase of the QBO than during the east phase in both winter and summer. These authors found also intensification of the stationary PW number 1 during the east phase in November-December. This intensification was successfully simulated by Maillard et al. (1990) using a 3-D primitive equations model with a forced equatorial QBO. Our study shows an amplification of the 12 day-wave attributed to PW number 2 during the east phase of QBO. This result seems to be the opposite of the results of Holton and Tan (1980) who found an amplification of PW number 2 during the west phase (not statistically significant). However the results are not fully comparable because the lidar

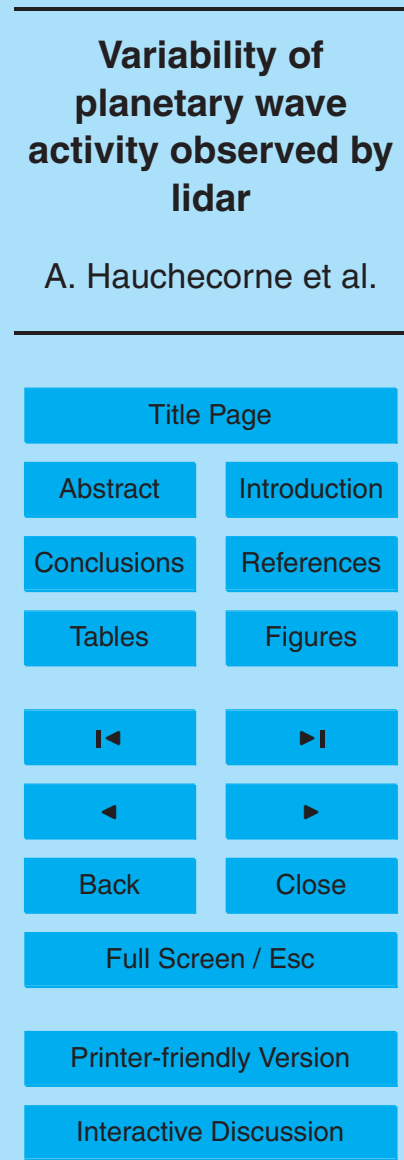


samples the propagating part of the PW field whereas Holton and Tan (1980) consider the stationary part.

The scatter plot of 12 day-wave energy versus QBO wind (Fig. 5) does not show a very linear anticorrelation but rather 2 families of data points, one below and one 5 above the regression line, each of them showing a clear anticorrelation. Borchi et al. (2005), using a wavelet multi-resolution analysis, identified 2 types of transition in TOMS (Total Ozone Mapping Spectrometer) Arctic ozone series from high winter variance to low spring variance, a first type with a very abrupt and early transition to the spring regime and the second type with a smooth evolution of ozone variance and 10 a late transition. It is interesting to note that the 3 winters with the highest PW energy (1984, 1987, 1992), all in QBO east phase, correspond to 3 winters of the second type. This seems to indicate that winters with a late transition to the quiet spring regime are also characterised by high average 12-day-wave energy.

The Brewer-Dobson circulation is at the origin of the poleward transport of ozone in 15 the stratosphere. It is driven by the dissipation of PW in the middle atmosphere and any change in PW activity will affect the total ozone content at mid and high latitude. Fusco and Salby (1999) and Salby and Callaghan (2002) proposed that the interannual variation of total ozone in the Northern Hemisphere is correlated with upwelling PW activity from the troposphere, estimated by the Eliassen-Palm (EP) flux at the tropopause.

20 Salby et al. (2002), using lidar data at OHP, showed that the interannual change in EP flux affects also the winter-time vertical structure of stratospheric ozone and temperature at mid-latitude. Randell et al. (2002) suggested that the EP flux entering into the stratosphere presents a general negative trend and contributes to $\sim 20-30 \%$ of the observed trend in column ozone over $35-60^{\circ} \mathrm{N}$ between 1979 and 2000 . There findings 25 were confirmed by Hood and Soukharev (2005) who showed also a $~ 30 \%$ contribution to the mid-latitude ozone negative trend of the synoptic wave forcing, characterised by Ertel's potential vorticity, in February-March. The present work confirms the negative trend in PW activity for months October to January (Fig. 5) but shows also a partially compensating effect in early spring (March-April) with a positive trend. The northern

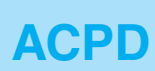

6, 11299-11316, 2006

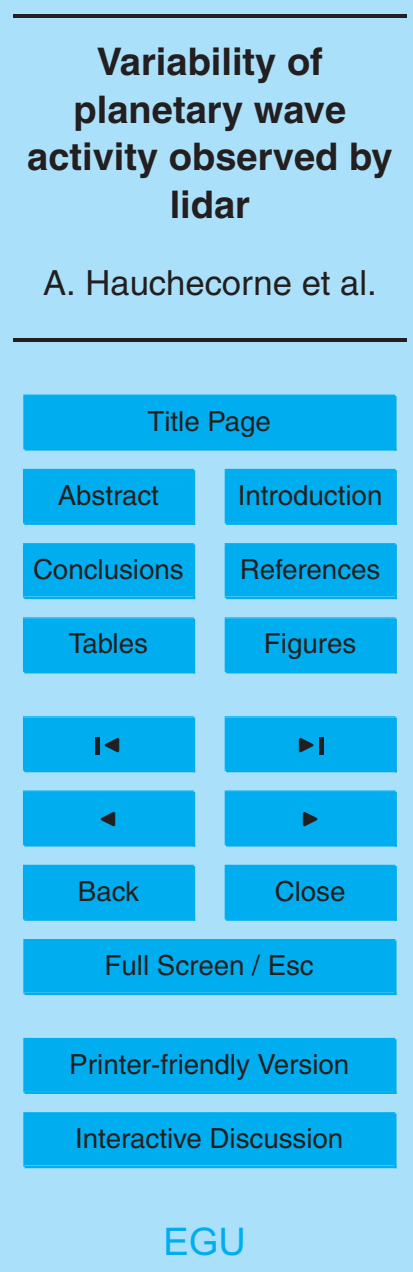


mid-latitude negative trend in total ozone is maximal in March and decreases during the following months (Fioletov and Shepherd, 2005). It would be interesting to study if the increase in PW activity in March-April contributes to the reduction of the negative trend in spring.

\section{Conclusions}

20 years of middle atmosphere Rayleigh lidar temperature data at OHP $\left(44^{\circ} \mathrm{N}\right)$ have been used to study the interannual variability of PW activity in winter (October to April). The main conclusions are as follows:

- the spectrum of the stratospheric temperature fluctuations exhibits 2 peaks around 16-20 and 12-13 days which are attributed to 2 dominant modes of free travelling Rossby waves known in the literature as the 16 day-number 1 and 12 day-number 2 waves;

- the 12 day wave activity presents a quasi 2 years periodicity anticorrelated with the equatorial QBO wind defined at $40 \mathrm{hPa}$;

- during the period 1981-2001, the PW activity shows a negative trend for months October to January, in agreement with previous studies showing a weakening of Brewer-Dobson circulation during these months (Salby and Callaghan, 2002; Randell et al., 2002; Hood and Soukharev, 2005), and a positive trend for March and April. It would be interesting to study if the increase in PW activity in early spring contributes to the reduction of the negative trend in northern mid-latitude total ozone observed by (Fioletov and Shepherd, 2005) between March and June.

\section{References}

Austin, J., Shindell, D., Beagley, S. R., et al.: Uncertainties and assessments of chemistryclimate models of the stratosphere, Atmos. Chem. Phys., 3, 1-27, 2003.

\section{Variability of planetary wave activity observed by lidar}

\section{A. Hauchecorne et al.}

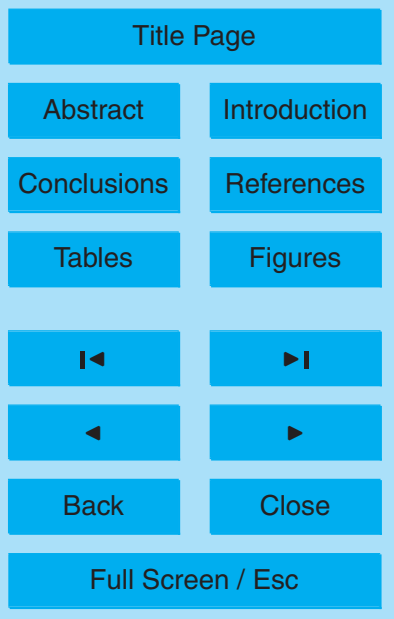

Printer-friendly Version

Interactive Discussion 
Bittner, M., Offermann, D., Bugaeva, I. V., et al.: Long period/large scale oscillations of temperature during DYANA campaign, J. Atmos. Terr. Phys., 56, 1675-1700, 1994.

Borchi, F., Naveau, P., Keckhut, P., and Hauchecorne, A.: Detecting variability changes in Arctic total ozone column, J. Atmos. Sol.-Terr. Phys., 68, 1383-1395, doi:10.1016/j.jastp.2006.05.011., 2006.

Charney, J. G. and Drazin, P. G.: Propagation of planetary scale disturbances from the lower into the upper atmosphere, J. Geophys. Res., 66, 83-109, 1961.

Cordero, E. C. and Nathan, T. R.: A new pathway for communicating the 11-year solar cycle signal to the QBO, Geophys. Res. Lett., 32, L18805, doi:10.1029/2005GL023696, 2005.

10 Fioletov, V. E. and Shepherd, T. G.: Summertime total ozone variations over middle and polar latitudes, Geophys. Res. Lett., 32, L04807, doi:10.1029/2004GL022080, 2005.

Fusco, A. C. and Salby, M. L.: Interannual Variations of Total Ozone and Their Relationship to Variations of Planetary Wave Activity, J. Clim., 12, 1619-1629, 1999.

Hauchecorne, A. and Chanin, M. L.: Density and temperature profiles obtained by lidar between

$15 \quad 35$ and 70 km, Geophys. Res. Lett., 7, 565-568, 1980.

Hauchecorne, A. and Chanin, M. L.: Mid-latitude observations of planetary waves in the middle atmosphere during the winter of 1981-1982, J. Geophys. Res., 88, 3843-3849, 1983.

Hauchecorne, A., Blix, T., Gerndt, R., Kokin, G. A., Meyer, W., and Shefov, N. N.: Large-scale coherence of the mesospheric and upper stratospheric temperature fluctuations, J. Atmos.

$20 \quad$ Terr. Phys., 49, 649-654, 1987.

Hauchecorne, A., Chanin, M. L., and Keckhut, P.: Climatology and trends of the middle atmospheric temperature $(33-87 \mathrm{~km})$ as seen by Rayleigh lidar above south of France, J. Geophys. Res., 96, 15297-15309, 1991.

Hedin, A. E.: Extension of the MSIS thermosphere model into the lower atmosphere, J. Geophys. Res., 96, 1159-1172, 1991.

Holton, J. R. and Tan, H.-C.: The influence of the equatorial quasibiennial oscillation on the global circulation at $50 \mathrm{MB}$, J. Atmos. Sci., 37, 2200-2208, 1980.

Hood, L. L. and Soukharev, B. E.: Interannual variations of total ozone at northern midlatitudes correlated with stratospheric EP flux and potential vorticity, J. Atmos. Sci., 62, 3724-3740, $30 \quad 2005$.

Kasahara, A.: Effect of Zonal Flows on the Free Oscillations of a Barotropic Atmosphere, J. Atmos. Sci., 37, 917-929, 1980.

Keckhut, P., Hauchecorne, A., and Chanin, M. L.: A critical review of the data base acquired for

\section{Variability of \\ planetary wave \\ activity observed by \\ lidar}

A. Hauchecorne et al.

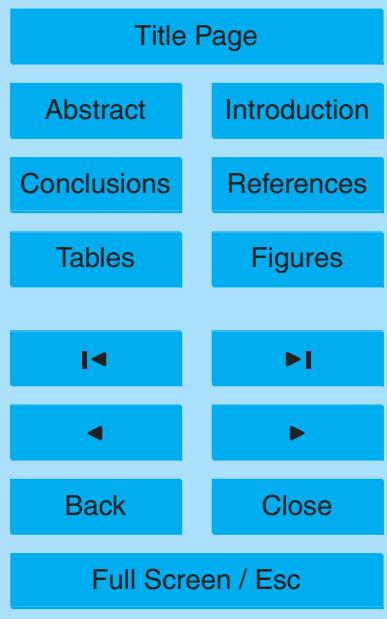

Printer-friendly Version

Interactive Discussion 
the long term surveillance of the middle atmosphere by Rayleigh lidar, J. Atm. Ocean. Tech., 10, 850-867, 1993.

Keckhut, P., Hauchecorne, A., and Chanin, M. L.: Mid-latitude long-term variability of the middle atmosphere: trends, cyclic and episodic changes, J. Geophys. Res., 100, 18887-18897, 1995.

Labizke, K.: Stratospheric-mesospheric midwinter disturbances - A summary of observed characteristics, 1981, J. Geophys. Res., 86, 9665-9678, 1981.

Maillard, A., Hauchecorne, A., and Rose, K.: Planetary waves modulated by the Quasi-Biennial Oscillation (QBO), Ann. Geophys., 8, 531-540, 1990.

10 Matsuno, T.: A dynamical model of the stratospheric sudden warming, J. Atmos. Sci., 28, 1479-1494, 1971.

Naujokat, B., Labitzke, K., Lenschow, R., Petzoldt, K., and Wohlfahrt, R.-C.: The stratospheric winter 1986/87: A major midwinter warming 35 years after they were first detected, Beilage zur Berliner Wetterkarte, SO 9/87, 1987.

Offermann, D., Gerndt, R., Küchler, R., et al.: Mean state and long term variations of temperature in the winter middle atmosphere above northern Scandinavia, J. Atmos. Terr. Phys., 49, 655-674, 1987.

O'Neill, A. and Youngblut, C. E.: Stratospheric warmings diagnosed using the transformed Eulerian-mean equations and the effect of the mean state on wave propagation, J. Atmos.

20 Sci., 39, 1370-1386, 1982.

Ramaswamy, V., Chanin, M.-L., Angell, J., et al.: Stratospheric Temperature Trends: Observations and Model Simulations, Rev. Geophys., 39(1), doi:10.1029/1999RG000065, 2001.

Randel, W. J., Wu, F., and Stolarski, R.: Chages in column ozone correlated with the stratospheric EP flux, J. Meteorol. Soc. Jap., 80, 849-862, 2002.

Salby, R. J. and Callaghan, P.: Interannual changes of the stratospheric circulation: Relationship to ozone and tropospheric structure, J. Clim., 15, 3673-3685, 2002.

Salby, M. L., Callaghan, P., Keckhut, P., Godin, S., and Guirlet, M.: Interannual changes of temperature and ozone: relationship between the lower and the upper stratosphere, J. Geophys. Res., 107(D18), 4342, doi:10.1029/2001JD000421, 2002.

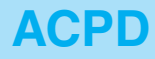

6, 11299-11316, 2006

\section{Variability of \\ planetary wave \\ activity observed by \\ lidar}

A. Hauchecorne et al.

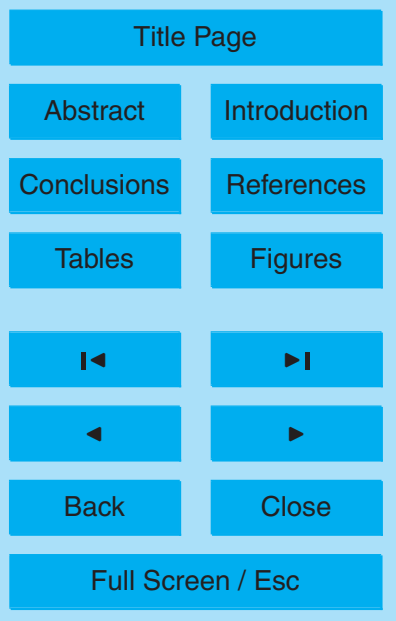

Printer-friendly Version

Interactive Discussion 


\section{ACPD}

6, 11299-11316, 2006

Table 1. Amplitude of equatorial wind in January-February at $40 \mathrm{hPa}$. QBO data series compiled by B. Naujokat, Stratospheric Research Group, Freie Universität Berlin, are available at http://strat-www.met.fu-berlin.de/products/cdrom/html/section5.html.

\begin{tabular}{lrlrrl}
\hline Year & Wind $\mathrm{m} / \mathrm{s}$ & QBO sign & Year & Wind $\mathrm{m} / \mathrm{s}$ & QBO sign \\
\hline 1982 & -14 & $\mathrm{E}$ & 1992 & -16.5 & $\mathrm{E}$ \\
1983 & 15 & $\mathrm{~W}$ & 1993 & 12.5 & $\mathrm{~W}$ \\
1984 & -8 & $\mathrm{E}$ & 1994 & -1.5 & $\mathrm{E}$ \\
1985 & -12 & $\mathrm{E}$ & 1995 & 5.5 & $\mathrm{~W}$ \\
1986 & 15 & $\mathrm{~W}$ & 1996 & 3.5 & $\mathrm{~W}$ \\
1987 & -9 & $\mathrm{E}$ & 1997 & -24 & $\mathrm{E}$ \\
1988 & 9 & $\mathrm{~W}$ & 1998 & 12.5 & $\mathrm{~W}$ \\
1989 & 12 & $\mathrm{~W}$ & 1999 & -14 & $\mathrm{E}$ \\
1990 & -26 & $\mathrm{E}$ & 2000 & 12 & $\mathrm{~W}$ \\
1991 & 11.5 & $\mathrm{~W}$ & 2001 & -7 & $\mathrm{E}$ \\
\hline
\end{tabular}

\section{Variability of planetary wave activity observed by lidar}

\section{A. Hauchecorne et al.}

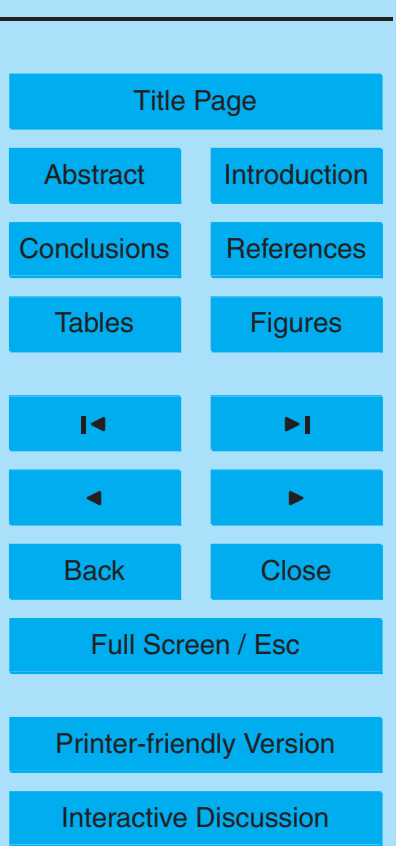




\section{ACPD}

6, 11299-11316, 2006

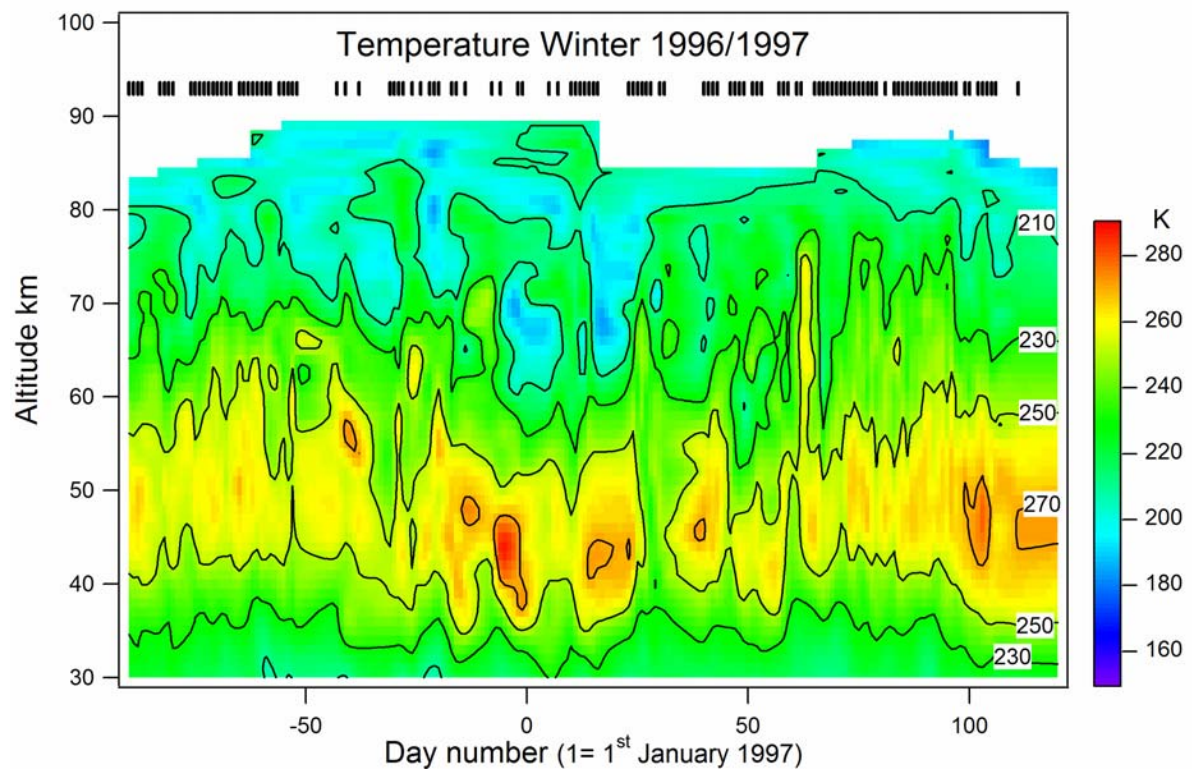

Fig. 1. Evolution of the temperature at OHP during winter 1996-1997. The days with measurements are indicated with a vertical bar at the top of the figure.

\section{Variability of planetary wave activity observed by lidar}

A. Hauchecorne et al.

Title Page

Abstract Introduction

Conclusions

References

Tables

Figures

14

$>1$

4

Back

Close

Printer-friendly Version

Interactive Discussion 


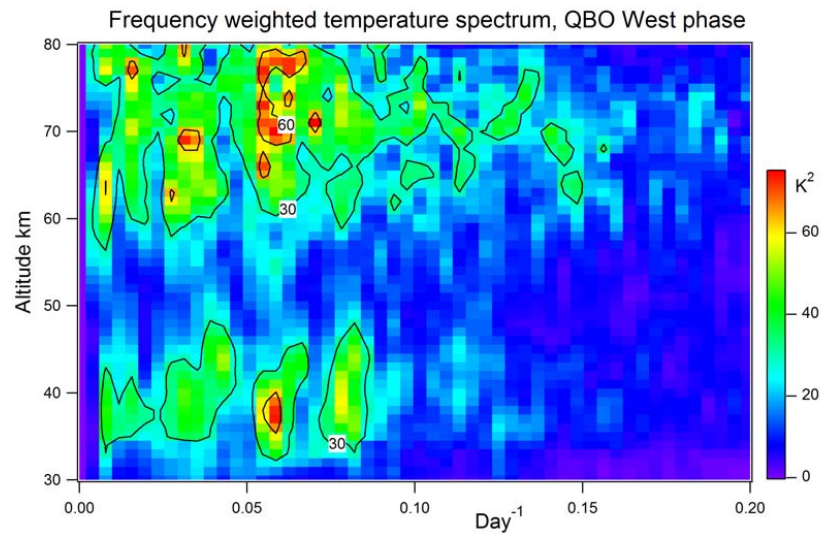

\section{ACPD}

6, 11299-11316, 2006

\section{Variability of planetary wave activity observed by lidar}

\section{A. Hauchecorne et al.}

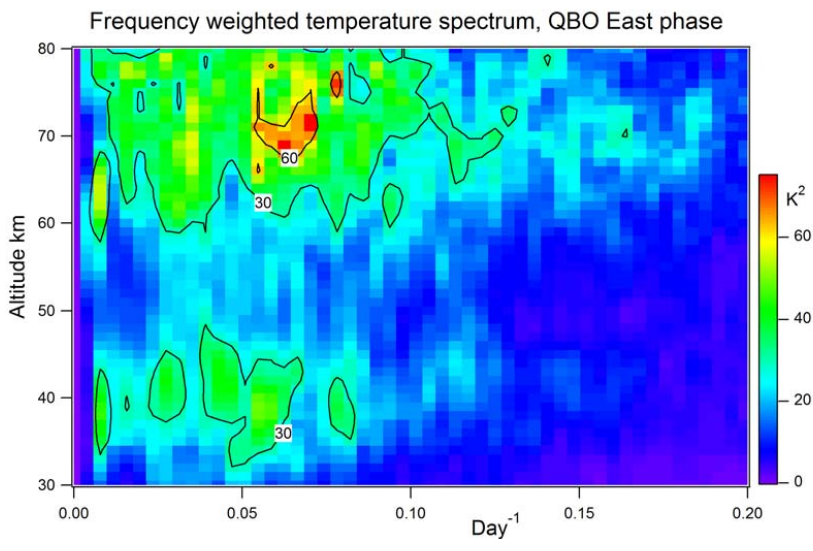

Title Page

Abstract

Conclusions
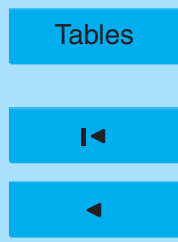

Back
Introduction

References

Figures

$\rightarrow$

$\checkmark$

Close

Full Screen / Esc

Printer-friendly Version

Interactive Discussion

Fig. 2. Energy spectrum of temperature perturbations averaged over winters in QBO West phase (top) and QBO East phase (bottom). The spectrum is multiplied by the frequency to have a better visualisation of energy maxima due to dominant PW modes. The non-weighted spectrum is dominated by the decrease of energy with frequency. Consequently the unit is $\mathrm{K}^{2}$ day $^{-1} /$ day $^{-1}=\mathrm{K}^{2}$. See Table 1 for the classification of QBO phases. 


\section{ACPD}

6, 11299-11316, 2006

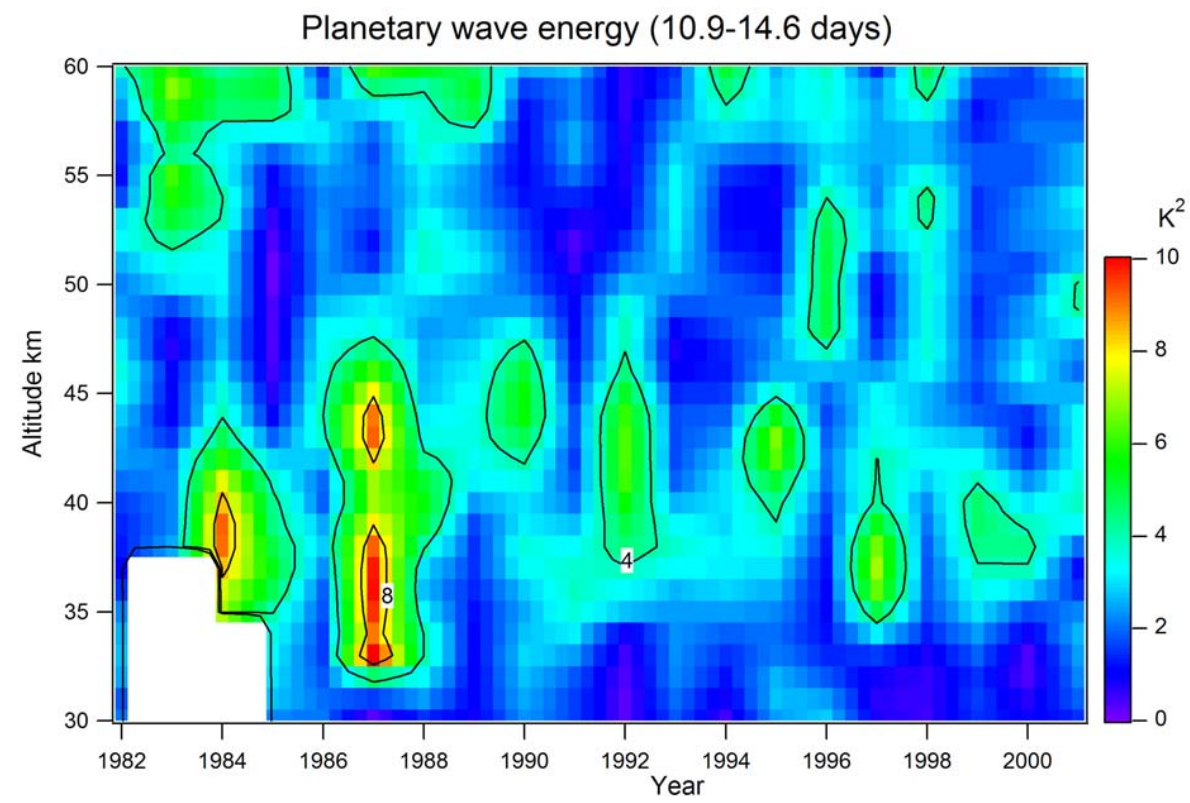

\section{Variability of planetary wave activity observed by lidar}

\section{A. Hauchecorne et al.}

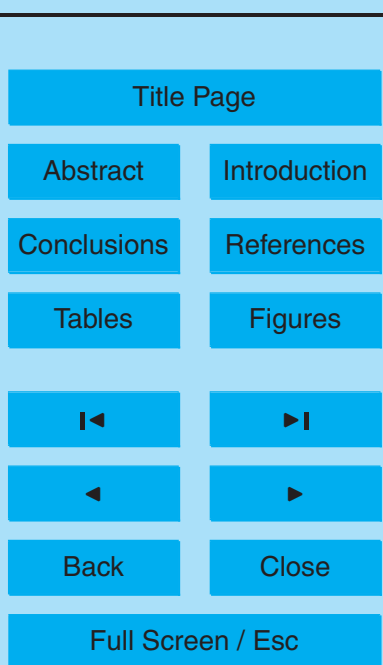

Fig. 3. Time-altitude section of the energy of the 12 day-wave. Years written on the $x$ label axis correspond to the end of winters (1982 for winter 1981-1982).

Printer-friendly Version

Interactive Discussion 


\section{ACPD}

6, 11299-11316, 2006

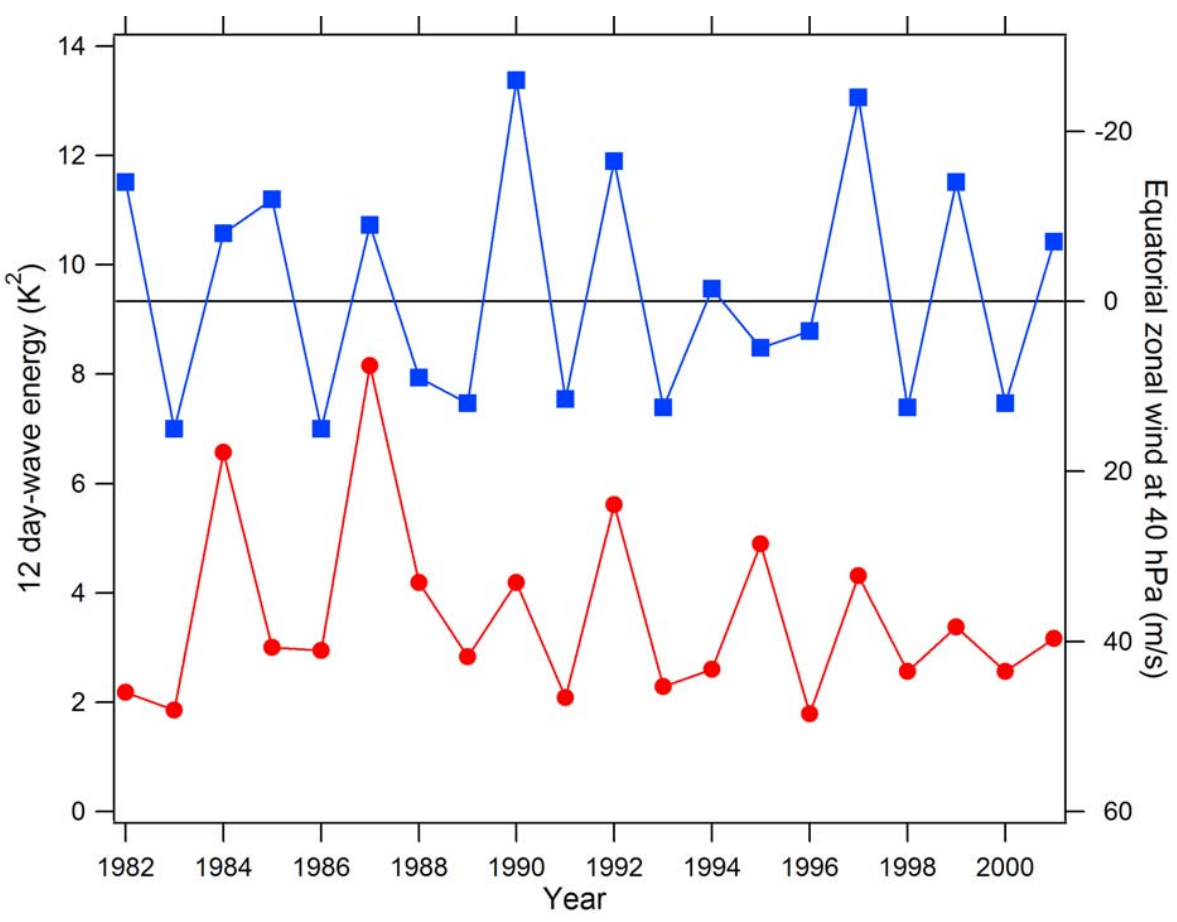

\section{Variability of planetary wave activity observed by lidar}

\section{A. Hauchecorne et al.}

Title Page

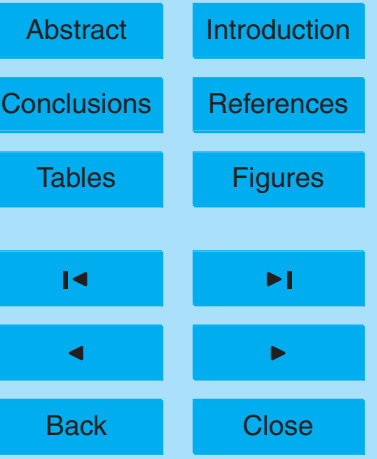

Full Screen / Esc

Fig. 4. Energy of 12 the day-wave averaged in the altitude range $38-45 \mathrm{~km}$ (bottom curve, left scale) and Equatorial zonal wind at $40 \mathrm{hPa}$ (top curve, inverted scale on the right).

Printer-friendly Version

Interactive Discussion 


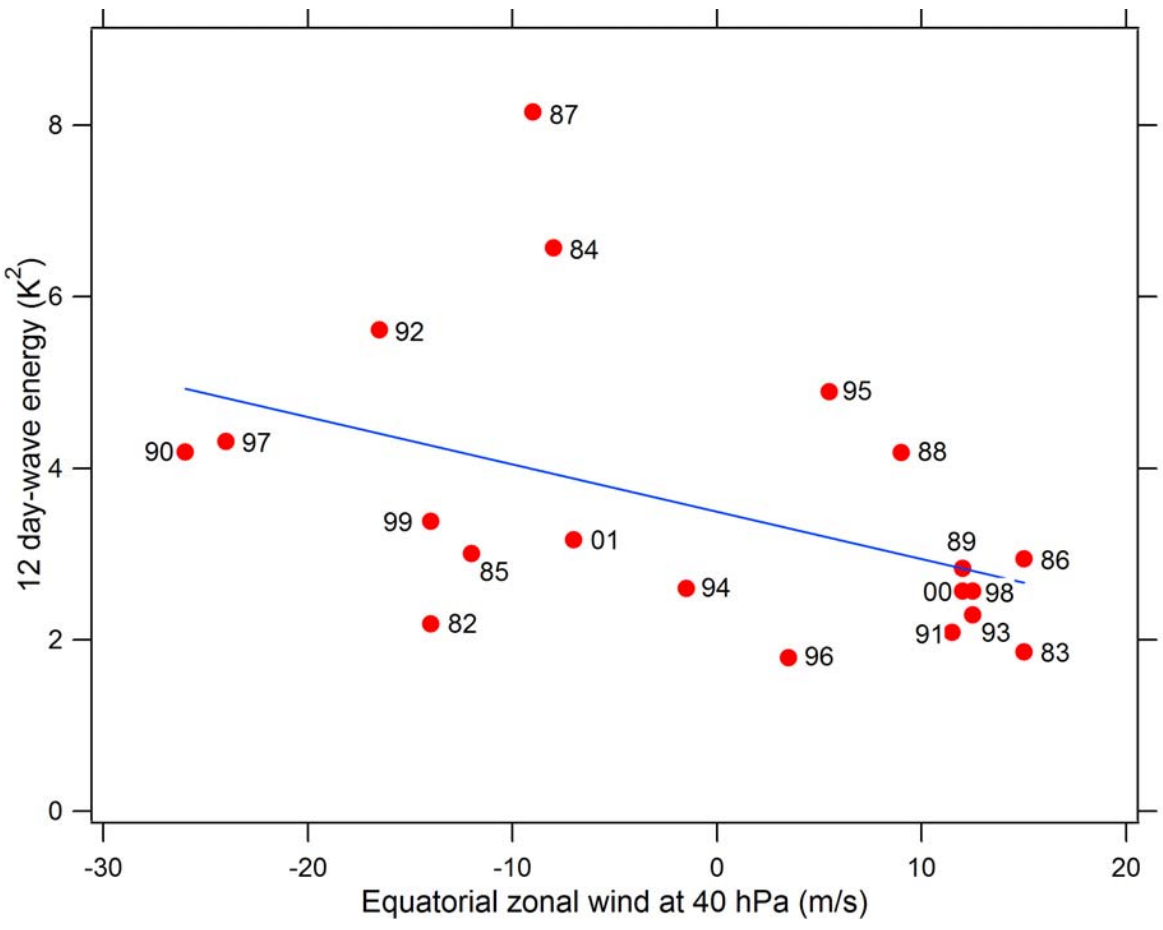

Fig. 5. 12 day-wave energy averaged in the altitude range $38-45 \mathrm{~km}$ versus Equatorial zonal wind at $40 \mathrm{hPa}$.

\section{ACPD}

6, 11299-11316, 2006

\section{Variability of planetary wave activity observed by lidar}

\section{A. Hauchecorne et al.}

\section{Title Page}

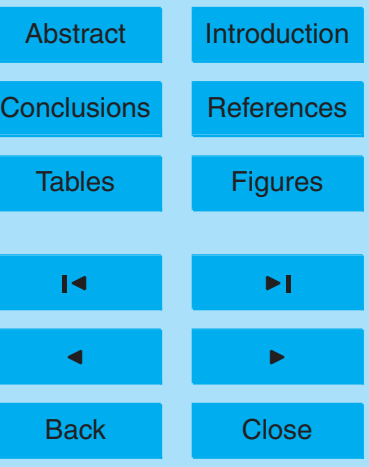

Full Screen / Esc

Printer-friendly Version

Interactive Discussion 


\section{ACPD}

6, 11299-11316, 2006

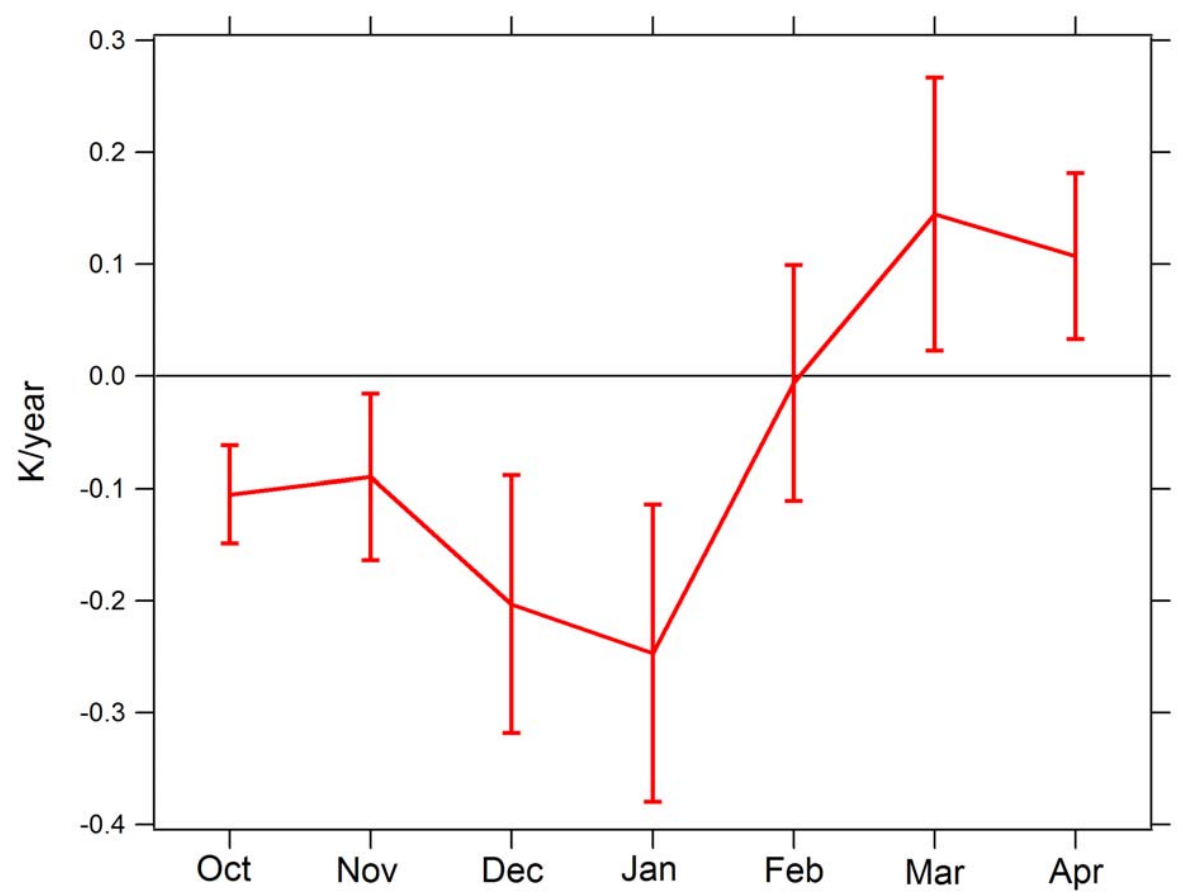

\section{Variability of planetary wave activity observed by lidar}

\section{A. Hauchecorne et al.}

\section{Title Page}

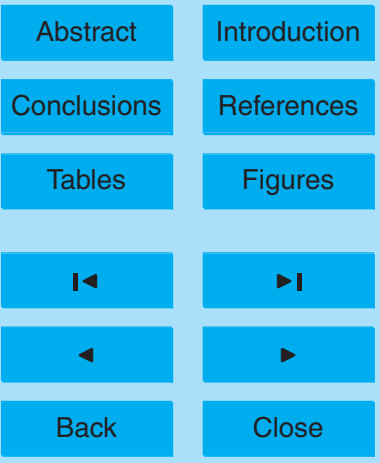

Full Screen / Esc

Fig. 6. Trend in planetary wave amplitude between 1982 and 2000 at $40 \mathrm{~km}$ from October to April. For each month, the PW amplitude is defined as the square root of the variance of temperature perturbations attributed to planetary waves (periods from 10 to 40 days).

Printer-friendly Version

Interactive Discussion 